\title{
Formation of the South Pacific Shallow Salinity Minimum: A Southern Ocean Pathway to the Tropical Pacific
}

\author{
JOHANNES KARSTENSEN* \\ Centro de Investigación Oceanográfica (COPAS), Programa Regional de Oceanografía Física y Clima (PROFC), \\ Universidad de Concepción, Concepción, Chile
}

(Manuscript received 21 April 2003, in final form 19 April 2004)

ABSTRACT

In the eastern South Pacific Ocean, at a depth of about $200 \mathrm{~m}$, a salinity minimum is found. This minimum is associated with a particular water mass, the "Shallow Salinity Minimum Water" (SSMW). SSMW outcrops in a fresh tongue $\left(S_{\min }\right)$ centered at about $45^{\circ} \mathrm{S}$. The $S_{\min }$ appears to emanate from the eastern boundary, against the mean flow. The watermass transformation that creates SSMW and $S_{\min }$ is investigated here. The $S_{\min }$ and SSMW are transformed from saltier and warmer waters originating from the western South Pacific. The freshening and cooling occur when the water is advected eastward at the poleward side of the subtropical gyre. Sources of freshening and cooling are air-sea exchange and advection of water from south of the subtropical gyre. A freshwater and heat budget for the mixed layer reveals that both sources equally contribute to the watermass transformation in the mixed layer. The freshened and cooled mixed layer water is subducted into the gyre interior along the southern rim of the subtropical gyre. Subduction into the zonal flow restricts the transformation of interior properties to diffusion only. A simple advection/diffusion balance reveals diffusion coefficients of order $2000 \mathrm{~m}^{2} \mathrm{~s}^{-1}$. The tongue shape of the $S_{\min }$ is explained from a dynamical viewpoint because no relation to a positive precipitation-evaporation balance was found. Freshest $S_{\min }$ values are found to coincide with slowest eastward mixed layer flow that accumulates the largest amounts of freshwater in the mixed layer and creates the fresh tongue at the sea surface. Although the SSMW is the densest and freshest mode of water subducted along the South American coast, the freshening and cooling in the South Pacific affect a whole range of densities $\left(25.0-26.8 \mathrm{~kg} \mathrm{~m}^{-3}\right)$. The transformed water turns northward with the gyre circulation and contributes to the hydrographic structure of the gyre farther north. Because the South Pacific provides most of the source waters that upwell along the equatorial Pacific, variability in South Pacific hydrography may influence equatorial Pacific hydrography. Because one-half of the transformation is found to be controlled through Ekman transport, variability in wind forcing at the southern rim of the subtropical gyre may be a source for variability of the equatorial Pacific.

\section{Introduction}

The tropical/extratropical exchange of water can be viewed as a meridional-vertical or subtropical cell (STC) driven by subduction and upwelling, which are connected via Ekman transport and interior flow. In the extratropics water is subducted from the mixed layer and flows equatorward in interior wind-driven pathways and western boundary currents. Near the equator this water upwells back into the mixed layer and is transported poleward to the subduction sites through the meridional component of the Ekman transport [see Schott

\footnotetext{
* Current affiliation: IFM-GEOMAR, Leibniz-Institut für Meereswissenschaften an der Universität Kiel, Kiel, Germany.

Corresponding author address: Johannes Karstensen, IFM-GEOMAR, Leibniz-Institut für Meereswissenschaften an der Universität Kiel, Dienstgebäude Westufer, Düsternbrooker Weg 20, 24105 Kiel, Germany.

E-mail: jkarstensen@ifm-geomar.de
}

et al. (2004) for an STC review]. STCs have been identified in all oceans using observational data (e.g., Johnson and McPhaden 1999; Schott et al. 2002; Zhang et al. 2003) and models (e.g., McCreary and Lu 1994; Rothstein et al. 1998).

One interest in studying the STCs is their potential involvement in low-frequency climate variability of the ocean-atmosphere system, because both upwelling and subduction are controlled through air-sea exchange of momentum, heat, and freshwater. In particular the variability of the Pacific Ocean STC is of importance, because it may be related to El Niño-Southern Oscillation (ENSO) with its far-reaching socioeconomic impacts. Pacific variability has been decomposed into interannual and interdecadal variability (Zhang et al. 1997). Interannual variability is usually associated with the ENSO phenomenon and may be explained through atmosphere-ocean interplay near the equator. Decadal variability, however, could be the result of variability that is generated in the extratropical ocean and subsequently advected to the equator. Two mechanisms have been 
proposed to generate variability based on temperature $(T)$ and transport (v). Kleeman et al. (1999) proposed a model solely based on fluctuations in STC transport, that is, without fluctuations in the temperature field $\left(\mathbf{v}^{\prime} \bar{T}\right)$. Fluctuations in transport generate sea-surface temperature fluctuations that could feed back on the atmospheric circulation. Observational evidence for transport fluctuations in the near-equatorial flow has been presented by, for example, McPhaden and Zhang (2002) and Meinen et al. (2001). Gu and Philander (1997) proposed a mechanism based on the advection of temperature anomalies with an average flow field $\left(\overline{\mathbf{v}} T^{\prime}\right)$. Subducted temperature anomalies in the extratropics appear with a time lag at the equator. Their upwelling causes temperature anomalies to appear in the Tropics that feed back onto the atmospheric meridional circulation. The appearance of a warm anomaly along the equator strengthens the extratropical wind and, through an increase of evaporation, introduces a cold anomaly in the extratropics. The subduction of such a cold anomaly then appears with a time lag along the equator where its upwelling initiates a cold anomaly there. However, the persistence of temperature anomalies subducted into the subtropical gyre is currently under debate. Hindcast runs of coupled ocean-atmosphere models suggest that equatorial Pacific isothermal depth variability may be generated by the local wind stress (and Ekman pumping) variability at the equator rather than from anomalies of extratropical origin (Schneider et al. 1999). In particular for the North Pacific little coupling between Tropics and extratropics was found. However, Yeager and Large (2004) identified sea-surface temperature variability along the equator generated through isopycnal advection of not only temperature but temperature/salinity $(T / S)$ anomalies. They analyzed output of an ocean model forced with 40 years of realistic surface fluxes. Their work emphasizes the role of both heat and freshwater anomalies in decadal variability.

McCreary and Lu (1994) showed that thermocline water moving equatorward originates from the east and poleward side of the subtropical gyres. This suggests for the South Pacific (SP) that the Southern Ocean (SO) can play a role in ventilating the Pacific equatorial thermocline (Toggweiler et al. 1991; Johnson 2001). A prominent exchange path from the SO toward the equator in all Southern Hemisphere oceans is the fresh tongue of Antarctic Intermediate Water (AAIW). AAIW has its origin in the subduction of polar surface waters (see, e.g., Molinelli 1978) and spreads at the base of the subtropical gyres, at depths between 600 and 1000 $\mathrm{m}$. However, with a core density anomaly of about 27.2 $\mathrm{kg} \mathrm{m}^{-3}$, AAIW lies below the water that upwells along the Pacific equator. Upwelling along the Pacific equator is, rather, fed in the density range of waters advected in the Equatorial Undercurrent (EUC) and the subsurface countercurrents (SCC) (Rowe et al. 2000), the subsurface pathways from west to east (and deep and shal-

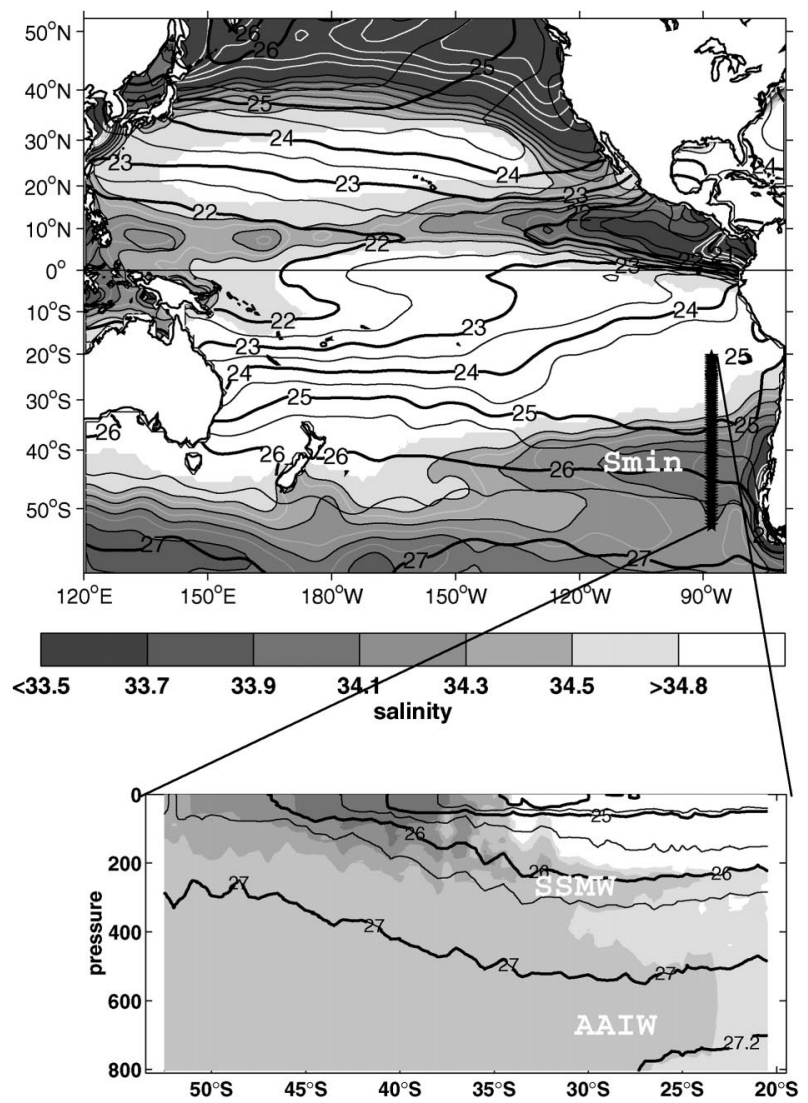

FIG. 1. (top) Mean sea surface salinity from World Ocean Database 1998 (Levitus et al. 1998). Salinity values from 33.5 to 34.8 are shaded, and sea surface density anomaly contours of $0.5 \mathrm{~kg} \mathrm{~m}^{-3}$ are overlaid. The fresh tongue is labeled $S_{\min }$, and the position of the section shown in the lower panel is marked. (bottom) Meridional salinity section, part of World Ocean Circulation Experiment (WOCE) line P19 (Tsuchiya and Talley 1998). The SSMW core and the AAIW core are labeled.

low) along the equator. The equatorial Pacific is fed by about $60 \%$ from the SP. The densest water that upwells is $26.8 \mathrm{~kg} \mathrm{~m}^{-3}$ (Johnson and McPhaden 1999; Rodgers et al. 2003).

A second fresh tongue is found above AAIW in the interior of the southeast SP (at about $26 \mathrm{~kg} \mathrm{~m}^{-3}$; see Fig. 1) named "Shallow Salinity Minimum Water" (SSMW; Reid 1973; Tsuchiya and Talley 1996) or Eastern South Pacific Intermediate Water (Emery and Meincke 1986; Schneider et al. 2003). SSMW is found in both hemispheres. Its formation has been explained through the sinking of subantarctic surface waters below higher-salinity waters (e.g., Reid 1973). Consequently one expects a corresponding signature in the sea surface salinity where SSMW is subducted. North Pacific surface waters freshen north of the subtropical gyre and along the eastern boundary (Fig. 1) so that the conceptual model for SSMW formation holds here. In the SP, however, a local meridional fresh tongue is located at about $45^{\circ} \mathrm{S}$. Consequently, a simple northward transfer 


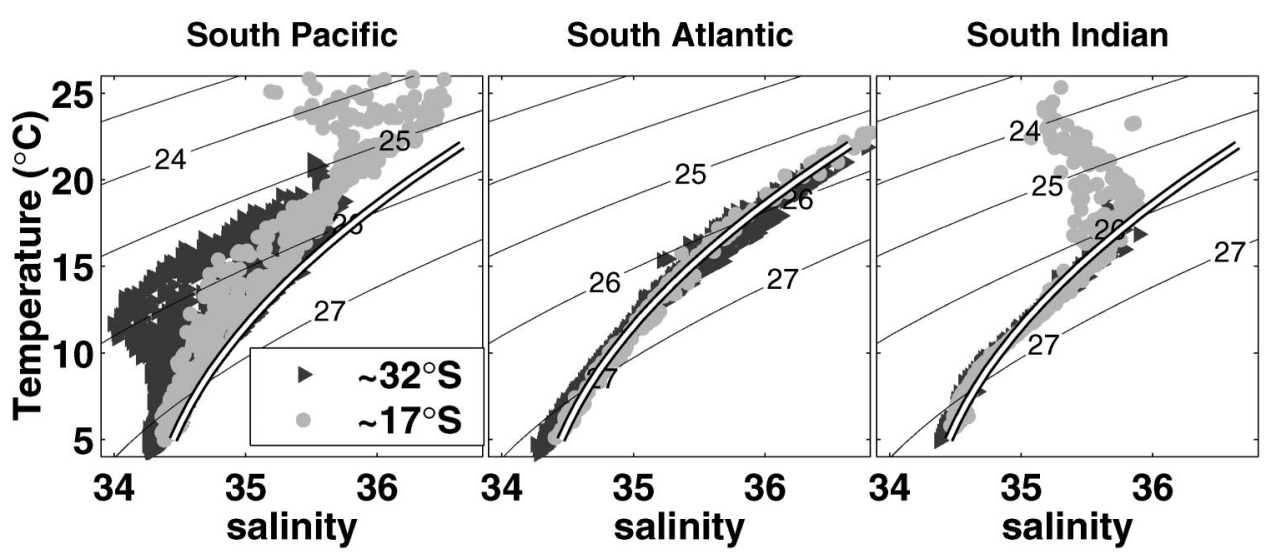

FIG. 2. Temperature-salinity diagrams of data along zonal sections in the South Pacific, South Atlantic, and southern Indian Ocean from WOCE data (WOCE Data Products Committee 2000). Thick black/white line is the second-order polynomial best fit to the Atlantic data.

of fresh surface water with subsequent subduction cannot explain the formation of SSMW in the SP entirely.

SSMW outcrops in a fresh surface tongue $\left(S_{\min }\right)$ (see Fig. 1). The shape of $S_{\min }$ prompted a number of investigators to infer a westward flow at the southern rim of the SP subtropical gyre (see Deacon 1977 for a review). Such a flow, in combination with coastal freshwater input and a positive precipitation-evaporation balance, was thought to generate the surface salinity pattern with lowest salinities in the east (Davila et al. 2002; Schneider et al. 2003). However, a clear signal of westward flow between the eastward-flowing subtropical gyre and the eastward-flowing extension of the ACC was never detected. Neshyba and Fonseca (1980) suspected transient eddies contributed to the westward transport but data coverage was too sparse to prove this idea.

In this paper we study watermass transformation in the southern part of the SP subtropical gyre to explain the formation of $S_{\min }$ and SSMW. After introducing the data, transformation mechanisms for mixed layer and thermocline waters are discussed. A zonal mixed layer budget is used to quantify the importance of air-sea exchange and advection. Then the role of diffusion in the watermass transformation is discussed. The formation of $S_{\min }$ is explained as an advective feature. Last, variability of the watermass transformation and its relation to decadal variability of the hydrographic structure of the SP and Equatorial Pacific are discussed.

\section{Data}

The ocean surface and interior data products used in this study are mainly the 1990-99 average temperature, salinity, and velocity fields from the beta-7 version of the simple ocean data assimilation (SODA) analysis (Carton et al. 2000a,b). SODA involves an optimal interpolation assimilation of data in a numerical model (the Modular Ocean Model MOM-2, GFDL, Princeton,
New Jersey). Sea surface temperature, altimeter sea surface height, and temperature and salinity profile data are assimilated. The model domain covers all oceans between $60^{\circ} \mathrm{S} / \mathrm{N}$ with a horizontal resolution of $1^{\circ} \times 1^{\circ}$ in latitude/longitude in the subtropics, $0.45^{\circ} \times 1^{\circ}$ in the Tropics. The model is optimized for physics of the upper ocean; 14 of its 20 vertical levels placed in the upper $500 \mathrm{~m}$. We will treat the SODA analysis fields as upperocean climatologies.

Surface flux momentum, evaporation, and precipitation fields are taken from the National Centers for Environmental Prediction (NCEP)-National Center for Atmospheric Research (NCAR) reanalysis (Kistler et al. 2001), which was also used to generate or force the SODA analysis (Carton et al. 2000b). Comparison studies between NCEP-NCAR reanalysis data and direct observations (e.g., Smith et al. 2001) found the NCEP data to overestimate fluxes (latent and sensible heat) by about $20 \mathrm{~W} \mathrm{~m}^{-2}$. This introduces an error for the net heat flux as well as for the freshwater flux (precipitation - evaporation balance) via latent heat. We decided to use both the original data (NCEP) and a version reduced by $20 \mathrm{~W} \mathrm{~m}^{-2}$ (NCEP-20W) for the calculations. For comparison, the Southampton Oceanographic Center (SOC) air-sea flux fields (Josey et al. 1998; Grist and Josey 2003) as well as the da Silva et al. (1994a,b) climatology are used. Both are based on observational data and both climatologies are "constrained" via a linear inverse analysis using hydrographic ocean heat transports.

\section{Upper-layer hydrography and dynamics}

The hydrographic structure of the SP subtropical gyre is complex in comparison with the other oceans. Temperature/salinity $(T-S)$ diagrams of zonal sections in the subtropics at $20^{\circ} \mathrm{S}$ and $30^{\circ} \mathrm{S}$ (Fig. 2) in the three oceans reveal that the interior of the SP cannot be characterized by a single Central Water "line" as in the southern 


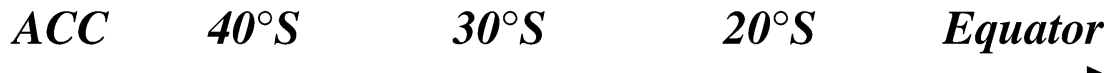

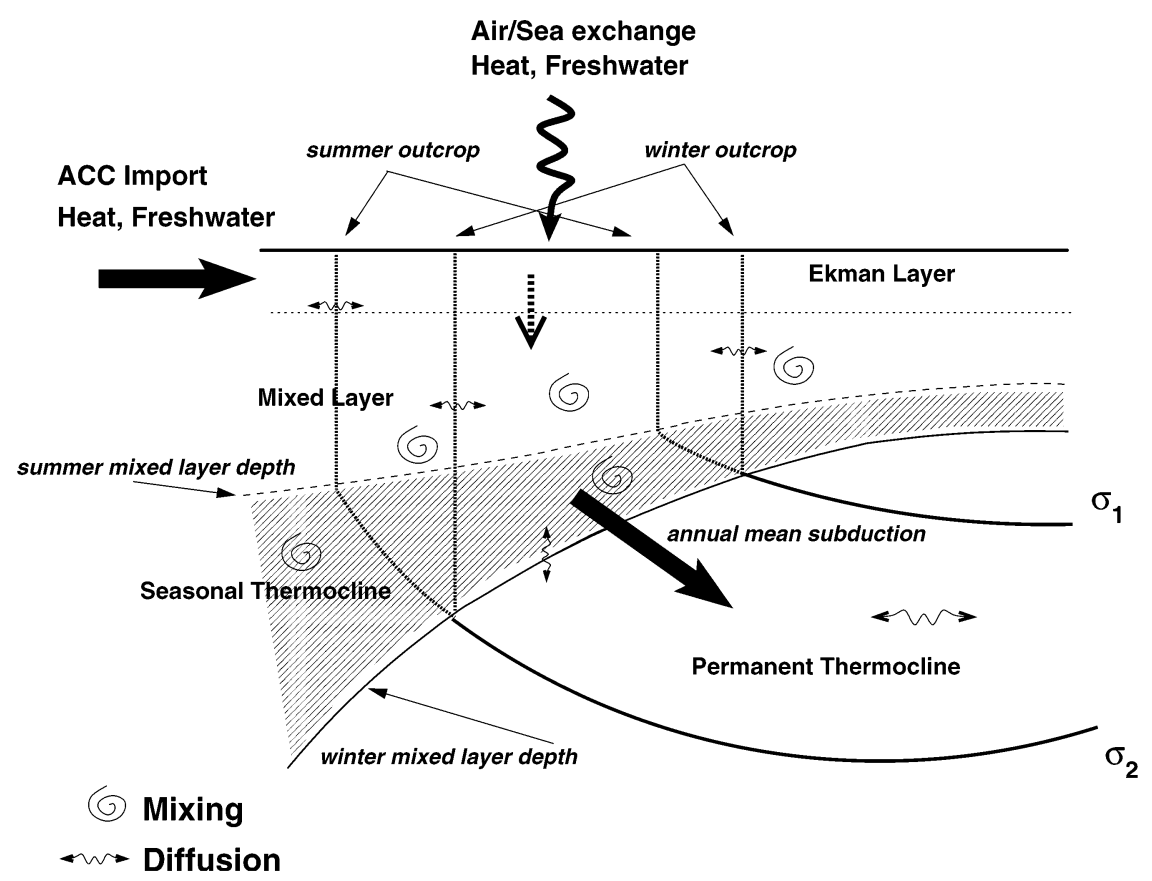

FIG. 3. A schematic meridional section through the subtropical gyre of the South Pacific. Two density anomaly surfaces $\left(\sigma_{1,2}\right)$ are depicted, and factors influencing the hydrographic properties between these two surfaces are sketched. See text for further explanation.

Indian and Atlantic Oceans, but shows more scatter, most pronounced at about $26 \mathrm{~kg} \mathrm{~m}^{-3}$. The southern Indian and Atlantic Oceans are quite similar in their $T / S$ distributions over the density range $26-27 \mathrm{~kg} \mathrm{~m}^{-3}$, which matches also the western SP characteristic. Toward the east, however, the SP is considerably fresher and colder on isopycnals than the other two oceans. To investigate this feature we recall the mechanisms responsible for the transformation of properties of the mixed layer and the way the modified properties are transferred into the interior (Fig. 3).

The mixed layer is dominated by mixing on various time and space scales (see, e.g., Woods 1985). Water advected near the surface from other ocean regions, such as the fresher water from the ACC in the SP or rainwater, is rapidly blended into the mixed layer and change its properties. The interior connection with the mixed layer, the outcrop, migrates meridionally through the seasonal cycle of air-sea exchange, poleward in summer and equatorward in winter. This movement is accompanied by a seasonal stratification underneath the mixed layer, the seasonal thermocline. An important control surface in thermocline-mixed layer system is the base of the deepest mixed layer, usually found in late winter. Most dramatic changes in the depth of the mixed layer base usually occur between late winter and early spring. The depth change traps winter properties in the seasonal thermocline and a net flux from mixed layer into thermocline occurs (Stommel 1979; Woods 1985; CushmanRoisin 1987). However, exchange occurs year-round and can have both directions: flux out of the mixed layer (subduction) and into the mixed layer (obduction; Qiu and Huang 1995). The dominant ventilation time scales of the mixed layer are seasonal, excluding possible longer-term changes in the mixed layer topography and forcing. The interior/thermocline ventilation time scales depend on the volume of neighboring isopycnals and the annual mean subduction rate into the respective isopycnals. Ventilation times of the permanent thermocline are larger than a year, up to the order of decades.

Large-scale flow in the mixed layer is the sum of geostrophic and ageostrophic components (e.g., Wijffels et al. 1994). The ageostrophic component, mainly the Ekman current, dominates near the surface but vanishes with depth where the geostrophic component gain importance. The vertical integral of the Ekman current, the Ekman transport, constitutes the upper branch of the STC over large parts of the midlatitude subtropical gyres. At low latitudes an interior geostrophic return flow has also been documented (Wyrtki 1981). A direct estimate of the Ekman currents and associated transports is possible from a combination of hydrographic and ve- 
locity measurements (see, e.g., Wijffels et al. 1994). However, if one is only interested in the vertical integrated transport components, they can be derived from the meridional and zonal wind stress (e.g., Gill 1982). In contrast to the mixed layer, the thermocline is dominated by lateral/isopycnal transport of properties, rather weak cross-isopycnal mixing, and geostrophic flow.

\section{Surface forcing and mixed layer dynamics}

Watermass transformation occurs at boundaries through exchange processes or in the interior through mixing. Mixed layer water is constantly transformed through air-sea interaction, lateral advection in the mixed layer, and entrainment at the mixed layer base. Strongest advection in the mixed layer occurs near the surface by Ekman flow. Over large parts of the subtropical gyres the wind field is predominately zonal and consequently the Ekman transport is meridional (Fig. $4 a$ ). In the context of the STC, the zero meridional Ekman transport line, located in the SP at about $30^{\circ} \mathrm{S}$ (Fig. $4 \mathrm{a}$ ), is the separator between higher- and lower-latitude origin of the surface waters participating in the STC.

The zero meridional Ekman transport line coincides with a surface density anomaly of about $25 \mathrm{~kg} \mathrm{~m}^{-3}$ (Fig. 4b). Over one seasonal cycle (one year) the relative position between density and zero meridional Ekman transport is fairly fixed in the east while it is more variable in the west, changing in the Tasman Sea between $30^{\circ} \mathrm{S}$ in summer and $40^{\circ} \mathrm{S}$ in winter (not shown here). The reverse is true for the seasonal movement of the surface outcrop density (not shown here): In the west it follows the movement of the zero meridional Ekman transport $\left( \pm 0.2 \mathrm{~kg} \mathrm{~m}^{-3}\right)$ while in the east variability is higher $\left( \pm 0.5 \mathrm{~kg} \mathrm{~m}^{-3}\right)$.

Although the meridional Ekman transport dominates over large parts of the SP, the zonal Ekman transport plays a role in the eastern boundary upwelling region. It advects relatively cold and saline water from the upwelling region and explains the homogeneous and relative high surface density in the eastern subtropics (Fig. 4b).

Ocean heat loss (Fig. 4c) is intense in the western boundary current region and in the Tasman Sea. Here, warm tropical waters are advected poleward into regions underlying a colder atmosphere. High evaporation leading to high latent and sensible heat loss is a consequence. There is also high latent heat loss through evaporation in the region between $10^{\circ}$ and $30^{\circ} \mathrm{S}$ in the eastern SP. Intense heat gain occurs over the equatorial upwelling region and over the intense coastal upwelling along South America. The region south of the zero meridional Ekman transport shows patches of positive and negative heat flux. The heat gain between $40^{\circ}$ and $50^{\circ} \mathrm{S}$ from about $20^{\circ}$ to $80^{\circ} \mathrm{W}$ is a significant feature related to the northward advection of fresh and cold water through Ekman transport from the south as well as to a positive freshwater flux. Both advection and the positive fresh- water flux promote the formation of a shallow barrier layer in summer, blocking the vertical heat exchange, and surface waters warm more intensely. High interannual variability of the sea surface temperature in summer has been observed in this region (A. Montecinos 2002, personal communication), which is possibly related to the variability in barrier-layer intensity. The barrier layer is eroded in autumn/winter through convective overturning driven by heat loss.

A positive freshwater flux can be found south of $30^{\circ} \mathrm{S}$ (Fig. 4d) and is connected with the western equatorial Pacific through the South Pacific convergence zone (SPCZ). The SPCZ is a result of convergent flow around the Indonesian low and high pressure over the eastern subtropical South Pacific.

The surface pattern of Ekman transport as well as heat and freshwater fluxes suggests that the upper branch of the STC can be split into two transformation regions: One is for water denser than about $25 \mathrm{~kg} \mathrm{~m}^{-3}$ that is transformed south of $30^{\circ} \mathrm{S}$. This branch will be discussed below in more detail. The second branch is for water less dense than $25 \mathrm{~kg} \mathrm{~m}^{-3}$ that has its source in the equatorial upwelling. Here mixed layer water is transformed through the negative freshwater flux in the east and the positive freshwater flux in the west. We will not discuss this branch in detail.

To illustrate how the water parcels behave in the Ekman layer, trajectories were calculated for particles released at $5^{\circ}$ and $53^{\circ} \mathrm{S}$ (Fig. 4e). The average of the upper two layer velocities from the SODA analysis was used. The flow patterns are over large parts as one would expect from the Ekman layer transport (Fig. 4a). The trajectories are oriented meridionally and converge at $30^{\circ} \mathrm{S}$. Two regions are not reached by particles: In the southwest, west of New Zealand, particles have their origin farther west, south of Australia. This is in agreement with what we see from the interior properties suggesting western Pacific water to be similar to the southern Indian Ocean water (Fig. 2). The other exceptional region is between $10^{\circ}$ and $30^{\circ} \mathrm{S}$ in the eastern SP. The mixed layer here is populated through particles that originate from the eastern boundary upwelling.

From the Ekman transport divergence the mean vertical pumping term was derived (Fig. 4f). More or less the whole gyre is dominated by Ekman pumping. Exceptions are the eastern boundary upwelling region and under the SPCZ north of $20^{\circ} \mathrm{S}$. In general, Ekman pumping is stronger north of the zero meridional Ekman transport line.

\section{Exchanges between mixed layer and thermocline}

The mixed layer is not only modified through air-sea exchange and advection, but also through the net export of water through subduction at the base of the mixed layer (Fig. 3). Earlier SP studies (de Szoeke 1987; Huang and Qiu 1998; Karstensen and Quadfasel 2002) 

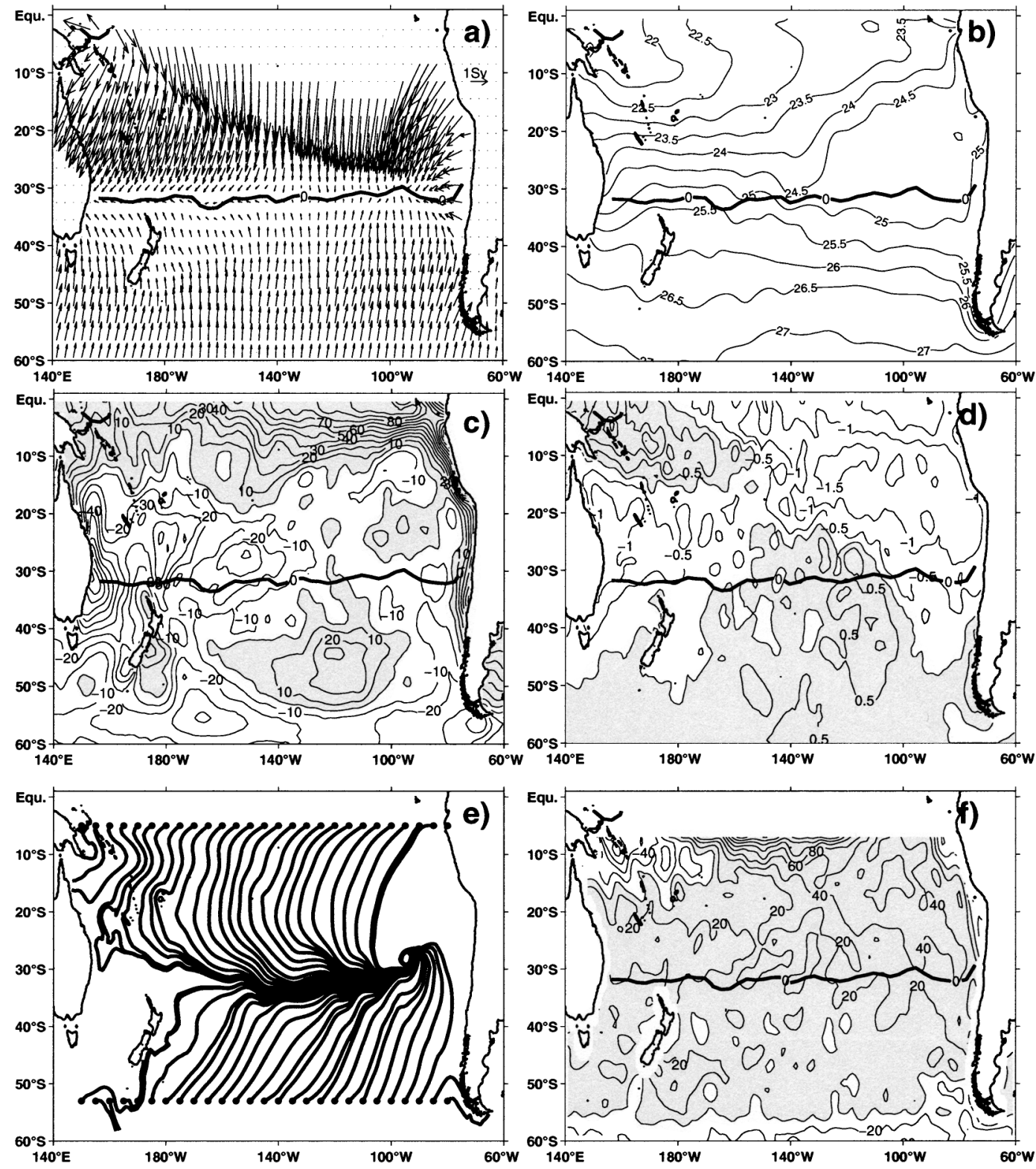

FIG. 4. (a) Magnitude and direction of Ekman transport derived from SOC wind stress data (Josey et al. 2002), (b) sea surface density field $\left(\mathrm{kg} \mathrm{m}^{-3}\right)$, and (c) constrained SOC net heat flux $\left(\mathrm{W} \mathrm{m}^{-2}\right)$ (Grist and Josey 2003). Heat gain by the ocean is gray shaded. (d) SOC freshwater flux [precipitation - evaporation $\left(\mathrm{m} \mathrm{yr}^{-1}\right)$, latent heat from Grist and Josey (2003)]; $P>E$ is gray shaded. (e) Trajectories of particles in the SODA analysis "Ekman layer" (upper two layers of the model). Particles are released at $53^{\circ}$ and $5^{\circ} \mathrm{S}$ every $5^{\circ}$ in longitude. (f) Ekman pumping $\left(\mathrm{m} \mathrm{yr}^{-1}\right)$ based on SOC wind stress data; downwelling is gray shaded. The thick line in all figures [except (e)] indicates the location of the zero meridional Ekman transport.

have shown that in our region of interest, south of $30^{\circ} \mathrm{S}$, the subtropical gyre is dominated by subduction. Consequently we consider in the following only the net export. Subduction in the SP has been analyzed by de Szoeke (1987) based on the classical Luyten et al. (1983) model, which accounts for an Ekman-pumpingdriven subduction only (cf. Fig. 4f). Later studies considered the seasonal mixed layer variability (Huang and Qiu 1998; Karstensen and Quadfasel 2002). However, for density anomalies smaller than $26.6 \mathrm{~kg} \mathrm{~m}^{-3}$ transports are similar in all publications and of order $25 \mathrm{~Sv}$ $\left(\mathrm{Sv} \equiv 10^{6} \mathrm{~m}^{3} \mathrm{~s}^{-1}\right)$.

The aforementioned studies focused mainly on the integral fluxes between the mixed layer and the thermocline, but in this study the regional distribution of water mass properties associated with the subduction is of interest. Because the subducted properties coincide with the properties of the deepest (austral winter) mixed 

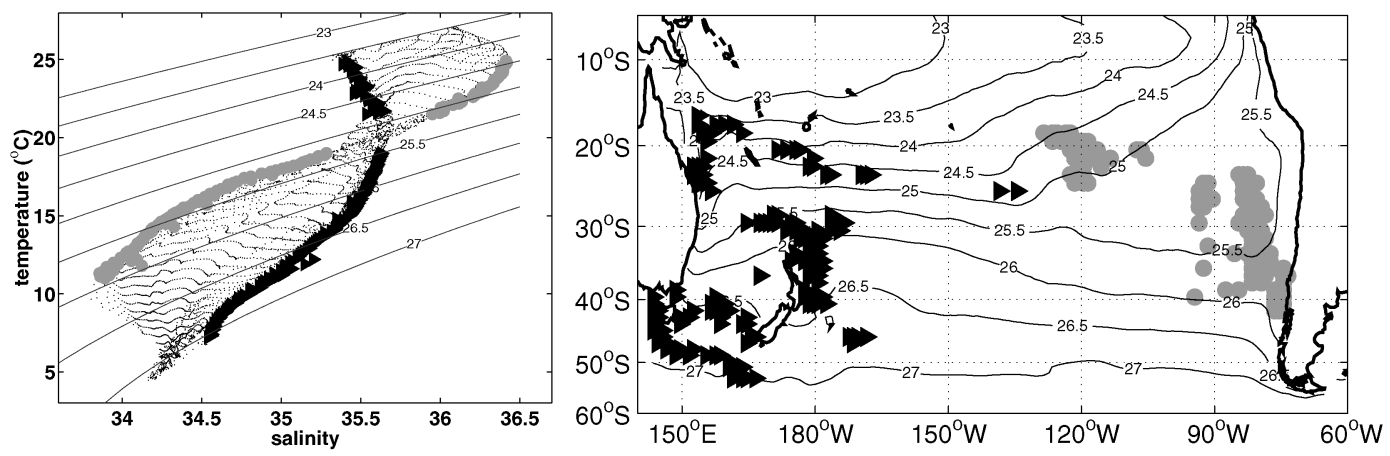

FIG. 5. (left) Winter mixed layer base temperature and salinity diagram with isopycnals. Small dots indicate water in the transition between eastern (gray circles) and western (black triangles) water. (right) Outcrop locations for eastern (gray circles) and western (black triangles) water. Winter mixed layer base density overlaid. See text for further details on how the areas have been found.

layer base, we searched for the highest and lowest values in the winter mixed layer base salinity for given temperature bins (gray dots and black triangles in Fig. 5). Each of the so determined $T-S$ pairs is associated with a subduction location (Fig. 5, right). For the density range from 24.0 to $26.0 \mathrm{~kg} \mathrm{~m}^{-3}$, two subduction regions are identified. Both incorporate equatorial upwelling as well as water from south of the zero meridional Ekman transport line. In the Tasman Sea, in the west, water with a nearly constant salinity of 35.5 and temperatures between $15^{\circ}$ and $25^{\circ} \mathrm{C}$ is subducted. Part of the water has been called South Pacific Subtropical Mode Water (Roemmich and Cornuelle 1992) although South Pacific Western Subtropical Mode Water (SPWSTMW) appears to be more appropriate to distinguish it from its eastern counterpart. The subducted waters denser than SPWSTMW resemble the $T-S$ properties of the other two Southern Hemisphere gyres (Fig. 2). Within the mode water density range but in the eastern SP, ventilation occurs over a much wider range of salinities from 34 to 36.5 and temperatures from $10^{\circ}$ to $25^{\circ} \mathrm{C}$, but they
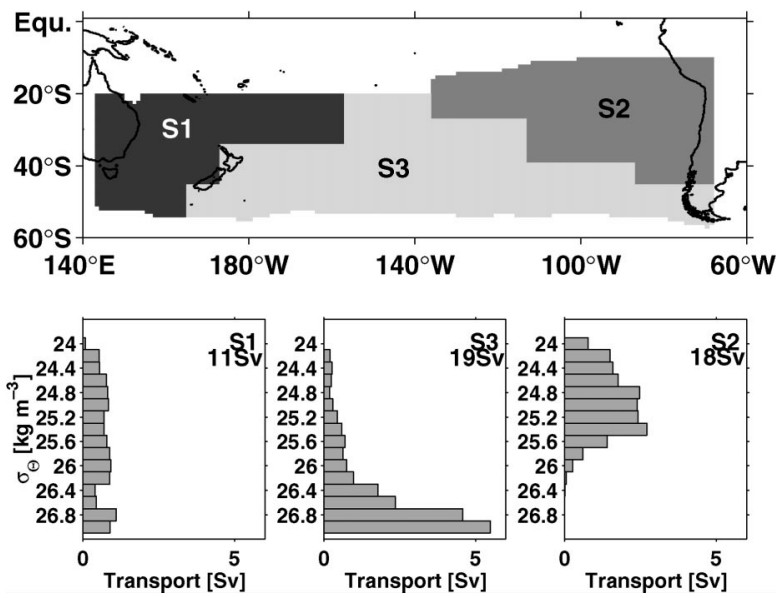

FIG. 6. (top) Subduction regions S1-S3 and (bottom) associated rates of watermass formation. Rates are derived based on Marshall et al. (1993). tend to compensate in density. Note the weak surface density gradient at the surface (Fig. 4b). Water subducted in this region has been termed South Pacific Eastern Subtropical Mode Water (SPESTMW; Hanawa and Talley 2001; Wong and Johnson 2003) and, as its western counterpart, incorporates equatorial and southern source waters. Last, a third subduction region is located at the southern rim of the SP subtropical gyre. Here, mixed layer water with characteristics in between western and eastern water is subducted and, as will be shown below, modifies the interior properties through lateral diffusion.

For each region [western (S1), eastern (S2), and southern (S3) (Fig. 6)], the annual mean subduction rate $\left(\mathcal{S}_{\text {ann }}\right)$ was evaluated from an analysis of the vertical velocities at the base of the winter mixed layer $(H)$ (Marshall et al. 1993):

$$
\mathcal{S}_{\text {ann }}=-w_{H}-\mathbf{u}_{H} \nabla H .
$$

Two contributions make up the annual mean subduction: 1) the "corrected" Ekman pumping term $\left(-w_{H}\right)$, which incorporates a correction for the meridional barotropic forcing of the mixed layer through the wind (Williams 1989), and 2) the component of the horizontal geostrophic flow perpendicular to the local tilt of the mixed layer base $\left(-\mathbf{u}_{H} \boldsymbol{\nabla} H\right)$.

We derived mean transports in density anomaly bins of $0.2 \mathrm{~kg} \mathrm{~m}^{-3}$ from the annual mean subduction rates and associated areas. The calculations were done with the 1990-99 average of the SODA velocities and hydrographic fields. The winter (September-October) mixed layer depth was derived as the depth at which the density exceeded the surface density by $0.125 \mathrm{~kg} \mathrm{~m}^{-3}$. The subduction rates calculated from the SODA analysis for the density range of interest agree well with the rates based on the World Ocean Atlas 1998 (WOA98) climatology (Karstensen and Quadfasel 2002). This confirms that the average SODA products are an adequate substitute for the WOA98 climatology and that the geostrophic flow with reference to $2000 \mathrm{dbar}$, as used in 
Karstensen and Quadfasel (2002), allows estimation of the wind-driven flow field of the SP.

Subduction rates in the east $(\mathrm{S} 2)$ and south $(\mathrm{S} 3)$ are both about $18 \mathrm{~Sv}$, while subduction in the west (S1) is only one-half, of order $10 \mathrm{~Sv}$ (Fig. 6, lower panels). As already mentioned, the water in the western region (S1) with density exceeding $26 \mathrm{~kg} \mathrm{~m}^{-3}$ has similar characteristics to the other two oceans, and the less-dense water above is much fresher. This freshening is the consequence of advection in the mixed layer from the western Pacific warm pool region where the surface waters are modified by a positive freshwater flux. In $\mathrm{S} 1$ the mixed layer water injected into the interior is rather evenly distributed in density, with $0.7 \mathrm{~Sv}$ in all $0.2 \mathrm{~kg}$ $\mathrm{m}^{-3}$ density bins. In the eastern subduction region (S2), water of densities between 24 and $26.2 \mathrm{~kg} \mathrm{~m}^{-3}$ is subducted. Water in the density range from 25.6 to 26.2 $\mathrm{kg} \mathrm{m}^{-3}$, which is formed at a rate of 2 to $3 \mathrm{~Sv}$, is what we regard as SSMW. However, largest transports are associated with the SEPSTMW with a formation rate of order $10 \mathrm{~Sv}$ for densities between 24.8 and $25.4 \mathrm{~kg} \mathrm{~m}^{-3}$. These values are similar to those given by Wong and Johnson (2003) based on results from Huang and Qiu (1998).

Last, the subduction along the southern rim of the subtropical gyre (S3) has the largest transfer of dense water when compared with the other two regions. Subduction here is mainly between 26.7 and $27.1 \mathrm{~kg} \mathrm{~m}^{-3}$, which is in the Subantarctic Mode Water range (McCartney 1977). AAIW subduction is not covered here because it occurs, with a core density of about $27.2 \mathrm{~kg}$ $\mathrm{m}^{-3}$, south of the data/model domain.

As a note, Carton et al. (2000a) compared synoptic sections with fields from the SODA analysis and found large differences in temperature and salinity at the base of the mixed layer. Differences increased toward the equator. They suspected weak subduction rates in the model and problems with the surface forcing, particularly freshwater fluxes. The weak subduction may be related to the way that the momentum is vertically distributed in the SODA underlying model. NCEP windstress-based Ekman transports (see below) are similar to the transport in the upper two layers $(\leq 22.5 \mathrm{~m})$ of the SODA analysis. This suggests that momentum flux is limited to the upper two layers in the SODA underlying model. Such shallow Ekman flow is in contrast to observational studies (e.g., Wijffels et al. 1994) that found Ekman flow as deep as $70 \mathrm{~m}$ in the lower subtropics. This ageostrophic flow may contribute significantly to the lateral component of subduction $\left(\mathbf{u}_{\text {ageo }, H} \boldsymbol{\nabla} H\right)$, in particular for the shallow depth near the equator, and may in part explain the too-low subduction rates in SODA. However, for the subduction rates we calculated for the subtropics this is less of a problem because the depth of the winter mixed layer base south of $30^{\circ} \mathrm{S}$ is on average about $80 \mathrm{~m}$ and too deep for a significant direct ageostrophic influence.

\section{Mixed layer freshwater and heat budget}

To quantify the relative importance of air-sea exchange and transport processes (northward Ekman transport, eddy-driven transport) a mixed layer heat and freshwater budget is constructed. We limit our calculations to the watermass transformation associated with the northward meridional Ekman transport. This region is characterized by increased freshening and cooling from west to east (Fig. 5, left). A basic assumption in our calculations is the zonal west-to-east transfer of water at the southern rim of the subtropical gyre. The existence and spatial structure of such a flow will be discussed in more detail below.

The budget is calculated in two steps: First we analyzed the freshwater $(\mathrm{FW})$ and heat $(H)$ needed to transform the mixed layer water with the western characteristics $\left(S_{\text {west }}, T_{\text {west }}\right)$ into mixed layer water of average characteristics $\left(S_{\text {average }}, T_{\text {average }}\right)$ :

$$
\begin{aligned}
\mathrm{FW}_{\text {zonal }} & =V\left(S_{\text {west }}-S_{\text {average }}\right) / S_{\text {average }} \quad \text { and } \\
H_{\text {zonal }} & =\rho_{0} c_{p} V\left(T_{\text {west }}-T_{\text {average }}\right) / t .
\end{aligned}
$$

Here $V$ is the mixed layer volume, $t$ is the time ( $1 \mathrm{yr}$ ), $\rho_{0}$ is a reference density $\left(1027 \mathrm{~kg} \mathrm{~m}^{-3}\right)$, and $c_{p}$ is the heat capacity (4000 $\mathrm{J} \mathrm{kg}^{-1} \mathrm{~K}^{-1}$ ). A positive number stands for adding $\mathrm{FW}$ or $H$ to the western waters. As we assume a steady state of the mixed layer, a time reference of one year is used to allow FW to be expressed as a flux or volume, while $H$ is expressed as flux.

Second, while water in the mixed layer is subducted during advection (Figs. 3 and 6), subduction is an additional source or sink of heat and freshwater for the mixed layer. The FW and $H$ fluxes through subduction are calculated from the difference between western characteristics $\left(T, S_{\text {west }}\right)$ and local (grid point) winter mixed layer base characteristics ( $S, T_{\text {MLbase }}$ ), because the winter mixed layer base water has the characteristics of the net exported waters (Stommel 1979). The volume of the subducted water is equal to the transport rates $(\Gamma)$ versus time $(t: 1 \mathrm{yr})$ :

$$
\begin{aligned}
\mathrm{FW}_{\text {subduction }} & =(\Gamma / t)\left(S_{\text {west }}-S_{\text {MLbase }}\right) / S_{\text {MLbase }} \text { and } \\
H_{\text {subduction }} & =\left(\rho_{0} c_{p} \Gamma / t\right)\left(T_{\text {west }}-T_{\text {MLbase }}\right) / t .
\end{aligned}
$$

Adding the zonal [Eq. (1)] and vertical [Eq. (2)] FW volumes and $H$ fluxes together results in the total FW and $H$ flux needed to maintain the water mass characteristic of the mixed layer:

$$
\begin{aligned}
\mathrm{FW}_{\text {total }} & =\mathrm{FW}_{\text {zonal }}+\mathrm{FW}_{\text {subduction }} \text { and } \\
H_{\text {total }} & =H_{\text {zonal }}+H_{\text {subduction }} .
\end{aligned}
$$

We computed these fluxes in $0.2 \mathrm{~kg} \mathrm{~m}^{-3}$ density bins, as is convenient for watermass conversion studies. Although our interest is in the budgets of the mixed layer, for sake of completeness, values for the mixed layer and thermocline are included in Figs. 7 and 8a, and Table 1. 


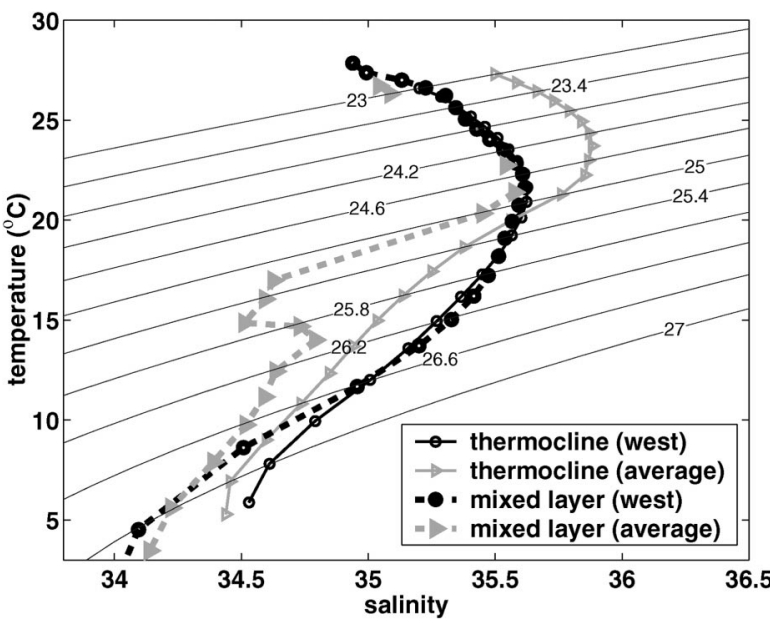

Fig. 7: Average $(\triangle)$ and western water $(\circ) T-S$ diagram of mixed layer (broken line) and thermocline (solid line). Note that the mixed layer characteristics are drawn only for waters within the northward Ekman transport.

\section{a. Zonal transformation}

Mixed layer and thermocline properties in the west are considerably fresher and colder than average characteristics for all densities between 25.2 and $26.8 \mathrm{~kg} \mathrm{~m}^{-3}$ (Fig. 7). Using Eq. (1), this corresponds to a positive freshwater volume (flux) of $15 \times 10^{12} \mathrm{~m}^{3}(0.48 \mathrm{~Sv})$ and a heat loss of $-0.29 \mathrm{PW}$ for the density range (Fig. 8a; Table 1).

For the thermocline the fluxes are 15 times as large (freshwater $200 \times 10^{12} \mathrm{~m}^{3}$ and heat flux $-4.0 \mathrm{PW}$ ), reflecting the longer ventilation time scale of the thermocline. Average and western mixed layer waters denser than $26.6 \mathrm{~kg} \mathrm{~m}^{-3}$ are always fresher and colder than average and western thermocline water of the same density. For those densities, subduction freshens/cools the interior. The mixed layer freshwater volume and heat loss have maxima at about $26.6 \mathrm{~kg} \mathrm{~m}^{-3}$ (Fig. 8a), while the respective thermocline maxima are denser at the 27.0 $\mathrm{kg} \mathrm{m}^{-3}$.

\section{b. Exchange through subduction}

During its pathway from west to east, there is a net export of water from the mixed layer into the thermocline. The net export occurs with the winter mixed layer base characteristics. From the difference between local mixed-layer base characteristics and the characteristics of the western water, again the freshwater volume and heat fluxes through subduction are calculated using Eq. (2). In the density range of interest we find a freshwater volume (flux) of $8 \times 10^{12} \mathrm{~m}^{3}(0.25 \mathrm{~Sv})$ and a heat loss of -0.14 PW through subduction (Fig. 8b).

\section{c. Maintenance of average mixed layer properties}

With the horizontal and vertical freshwater volumes (fluxes) and heat fluxes calculated, the total freshwater
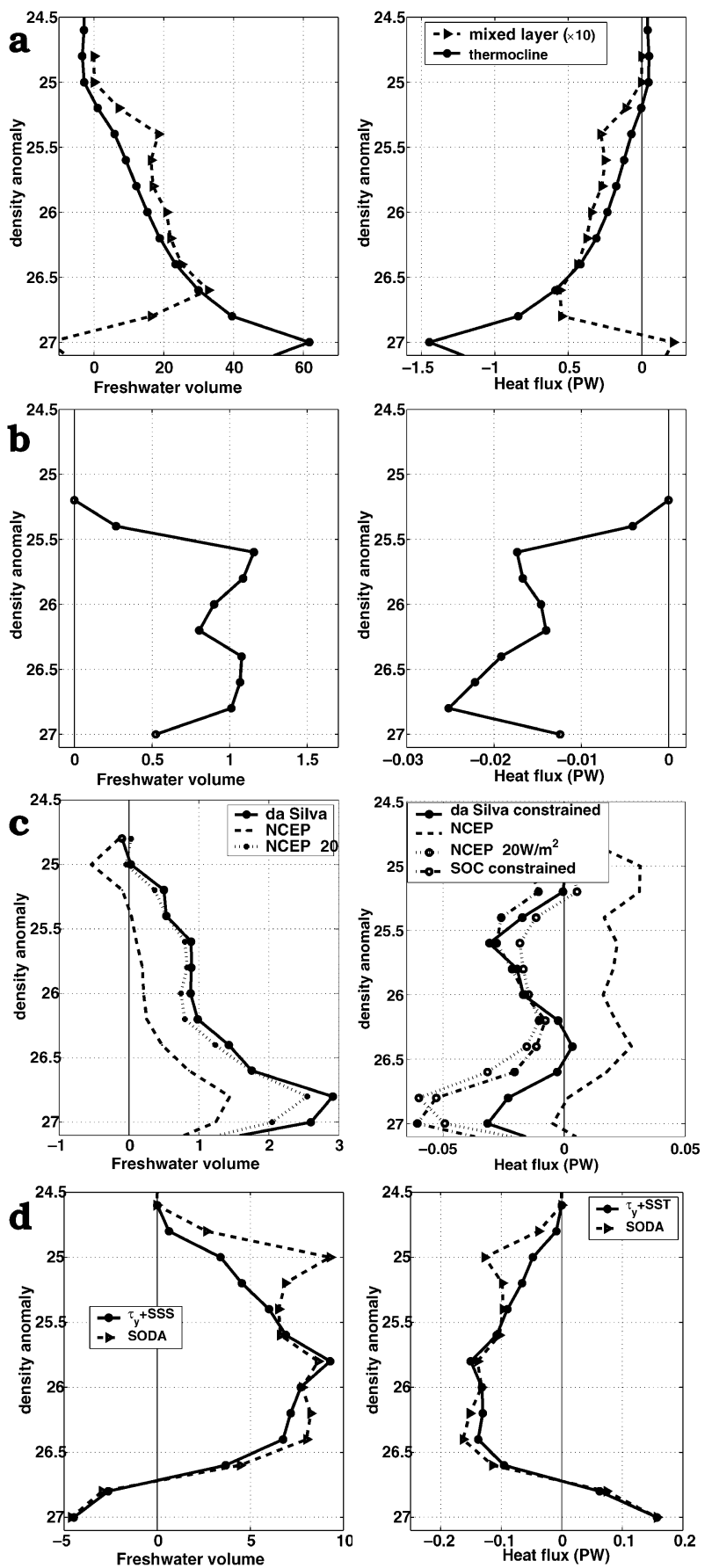

FIG. 8. (left) Freshwater volumes and (right) heat fluxes vs density (see text for further details). (a) Transformation of the western water into the average water (note that values for the thermocline are given for comparison only while mixed layer is rescaled by 10 to match the thermocline range). (b) Volume and fluxes subducted. (c) Airsea exchange volume and fluxes. (d) Volume and fluxes with the Ekman transport: (solid line) based on wind stress and SSS/SST, and (broken line) based on upper two levels of the SODA analysis fields. 
TABLE 1. Freshwater volume and heat flux associated with the watermass transformation in the South Pacific south of about $30^{\circ} \mathrm{S}$. Volumes are for a 1-yr period.

\begin{tabular}{|c|c|c|}
\hline $\begin{array}{c}\text { Dataset } \\
\left(\sigma_{\Theta} \text { range: } 24.8-27.0 \mathrm{~kg} \mathrm{~m}^{-3}\right)\end{array}$ & $\begin{array}{c}\text { Freshwater } \\
\text { volume }\left(10^{12} \mathrm{~m}^{3}\right.\end{array}$ & $\begin{array}{l}\text { Heat flux } \\
\left.0^{15} \mathrm{~W}=\mathrm{PW}\right)\end{array}$ \\
\hline \multicolumn{3}{|c|}{ Zonal transformation } \\
\hline SODA analysis & 15 & -0.29 \\
\hline \multicolumn{3}{|c|}{ Annual mean subduction } \\
\hline SODA analysis & 8 & -0.14 \\
\hline Total of first two rows & 23 & -0.43 \\
\hline \multicolumn{3}{|c|}{ Air-sea exchange } \\
\hline SOC & 14 & -0.25 \\
\hline Da Silva et al. $(1994 a, b)$ & 13 & -0.14 \\
\hline NCEP & 4 & +0.21 \\
\hline NCEP-20W & 12 & -0.22 \\
\hline \multicolumn{3}{|c|}{ Ekman transport } \\
\hline SODA analysis & 8 & -0.15 \\
\hline $\mathrm{NCEP}+\mathrm{SST} / \mathrm{SSS}$ & 9 & -0.15 \\
\hline \multicolumn{3}{|c|}{ Eddy transport } \\
\hline Roemmich and Gilson (2001) & - & -0.1 \\
\hline
\end{tabular}

volume (flux) $\mathrm{FW}_{\text {total }}=23 \times 10^{12} \mathrm{~m}^{3}(0.73 \mathrm{~Sv})$ and heat loss $H_{\text {total }}=-0.43 \mathrm{PW}$ are obtained as the sum of both components [Eq. (3)]. In the mean these volumes/ fluxes are needed to maintain the mixed layer watermass transformation within the region of northward meridional Ekman transport.

\section{d. Air-sea exchange}

The mean freshwater volume and heat flux through the air-sea exchange can be calculated directly from atmospheric datasets. Unfortunately, the quality of the air-sea flux products is often uncertain. This is particularly true for precipitation estimates, because it is localized in space and time and involves complicated dynamics and thermodynamics, which are difficult to parameterize and resolve in numerical models. To suggest possible errors a number of different datasets are used for the calculations.

Freshwater volume and heat fluxes based on SOC, da Silva et al. (1994a,b), and bias-corrected NCEP data (NCEP-20W) are similar in density class integrated fluxes (Table 1). We found a freshwater volume (flux) of order $10 \times 10^{12} \mathrm{~m}^{3}(0.32 \mathrm{~Sv})$ and a heat loss of order -0.2 PW. In addition, the surface density-related patterns are similar (Fig. 8c). The simple bias correction on NCEP of $20 \mathrm{~W} \mathrm{~m}^{-2}$ converts the original NCEP data from having a heat gain $(+0.2 \mathrm{PW})$ and only little positive freshwater flux into a heat loss, allowing for higher positive freshwater fluxes. The correction on NCEP compares better to the two observational data-based climatologies.

The freshwater and heat air-sea exchanges are similar to those calculated for the export through subduction (Table 1). This is in agreement with what is expected from the thermodynamics of subduction (Marshall et al. 1999). Even the density-related input pattern is similar (Figs. $8 \mathrm{~b}$ and $8 \mathrm{c}$, right), emphasizing the importance of heat flux in controlling buoyancy flux to drive subduction. In contrast, the freshwater input patterns of subduction and air-sea fluxes (Figs. $8 \mathrm{~b}$ and $8 \mathrm{c}$, left) are quite different, emphasizing a peculiarity of freshwater air-sea exchange: unlike heat flux anomalies, the freshwater anomalies do not feed back on the air-sea exchange, which makes a freshwater anomaly more persistent and allows for more efficient advection before export (subduction) into the interior.

To summarize, air-sea exchange contributes a freshwater volume (flux) of $12 \times 10^{12} \mathrm{~m}^{3}(0.38 \mathrm{~Sv})$ and heat loss of $-0.18 \mathrm{PW}$. This is about one-half of what is needed to maintain the SP mixed-layer watermass transformations of $23 \times 10^{12} \mathrm{~m}^{3}(0.73 \mathrm{~Sv})$ freshwater volume (flux) and $-0.43 \mathrm{PW}$ heat loss.

\section{e. Exchanges with the south}

Next we calculate the fluxes associated with Ekman transport and with the mesoscale eddy field. First the Ekman transport is inspected. Freshwater volumes and heat fluxes associated with the Ekman transport are derived in two different ways (Fig. 7d): 1) The divergences in the Ekman transport, calculated from the NCEP reanalysis wind stress field, are used in combination with changes in sea surface temperature (SST) and salinity (SSS). 2) The divergences of the average transport in the upper two layers of the SODA analysis in combination with the changes in the average properties (temperature and salinity) are used. Note, only the meridional transport is considered.

Both result in quite similar numbers: the sum of the meridional Ekman layer freshwater volume (flux) is $8 \times 10^{12} \mathrm{~m}^{3}(0.25 \mathrm{~Sv})$ and for the heat flux is -0.15 PW. Most of the northward flux is concentrated in the Subantarctic Mode Water density range (26.8 and 27 $\mathrm{kg} \mathrm{m}^{-3}$ ) for which we find a heat gain and a freshwater loss. This result is consistent with warming and salinification of upwelling water along the ACC frontal system. However, for SAMW densities the mixed layer is colder and fresher than the thermocline and on average subduction of mixed layer water would still cool and freshen the SP thermocline.

Next we inspected the potential contribution for the mixed layer watermass transformation through the eddy field. The wind-driven upwelling at the southern rim of the subtropical gyre, the "Deacon cell," maintains an upward tilting of isopycnals and is a source for potential energy. The potential energy is released through baroclinic instabilities that drive a residual meridional circulation directed against the Ekman-driven Deacon cell (Gent et al. 1995; Speer et al. 2000) that may allow for a heat loss of the subtropical gyre (e.g., Marshall et al. 2002). From repeat $X B T$ sections along $22^{\circ} \mathrm{N}$ in the North Pacific, Roemmich and Gilson (2001) estimated 


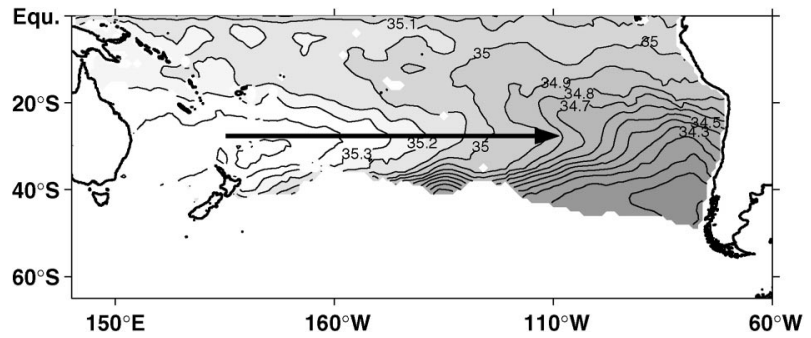

FIG. 9. Salinity distribution along density anomaly surface 26.1 $\mathrm{kg} \mathrm{m}^{-3}$. Note the salty tongue centered at about $30^{\circ} \mathrm{S}$, which is the core of the water from the western subduction region (S1) spreading eastward.

a poleward eddy heat transport of $5 \times 10^{12} \mathrm{~W}$ per eddy. For our estimate we utilized the Roemmich and Gilson (2001) results and rescaled them for $30^{\circ} \mathrm{S}$ and the width of the SP. We found a heat loss of -0.1 PW. Unfortunately, nothing is known about the freshwater fluxes associated with the eddy field.

Overall, Ekman transport divergence and the eddy fluxes may allow for a mixed layer heat loss of -0.2 $\mathrm{PW}$, which is on the order of the air-sea exchange (Table $1)$.

\section{Watermass transformation in the thermocline}

The zonal flow at the southern rim of the gyre at $30^{\circ} \mathrm{S}$ is an important pathway for the SP mixed layer and thermocline watermass transformation. The isolated character of the flow was recognized by Stramma et al. (1995) and associated with the southern rim of the subtropical gyre. This flow is, however, north of the South Pacific Current (Stramma et al. 1995), associated with the subtropical front. From the salinity distribution on $26.1 \mathrm{~kg} \mathrm{~m}^{-3}$ (Fig. 9) the flow can be identified as a salty tongue centered at $30^{\circ} \mathrm{S}$. The flow connects the subduction region in the west $(\mathrm{S} 1)$ and east (S2). During eastward advection the core salinity decreases through mixing with fresher water, subducted from the southern outcrop region (S3). For a zonal flow, lateral diffusion can play an important role in modifying interior properties (e.g., Gordon et al. 1997). A simple balance between horizontal advection $(u)$ and meridional diffusion was tested for the temperature $(T)$ and salinity $(S)$ distributions on isopycnal surfaces, allowing estimates of the strength of the attenuation of $T$ and $S$, expressed in a lateral diffusion coefficient $\left(K_{y}\right)$ :

$$
u \frac{\partial T}{\partial x}=K_{y} \frac{\partial^{2} T}{\partial y^{2}} \quad \text { and } \quad u \frac{\partial S}{\partial x}=K_{y} \frac{\partial^{2} S}{\partial y^{2}} .
$$

Lateral diffusion coefficients are derived using data between $160^{\circ}$ and $100^{\circ} \mathrm{W}$. The zonal gradients in $T$ and $S$ are quasi constant between these two longitudes. A hyperbolic fit to meridional gradients in temperature and salinity is applied using data in the latitude range from $40^{\circ}$ to $20^{\circ} \mathrm{S}$. We use an average eastward core speed of $1 \mathrm{~cm} \mathrm{~s}^{-1}$ with a depth dependence based on the average shear profile from the SODA analysis fields. The lateral diffusion coefficients $\left(K_{y}\right)$ obtained (Table 2) have a depth-weighted mean of about $3200 \mathrm{~m}^{2} \mathrm{~s}^{-1}$ for the 1 $\mathrm{cm} \mathrm{s}^{-1}$ core speed and about $2000 \mathrm{~m}^{2} \mathrm{~s}^{-1}$ taking the vertical velocity shear into account. The latter result matches the $2000 \mathrm{~m}^{2} \mathrm{~s}^{-1}$ used in the MOM-2 model underlying the SODA analysis. Using climatological temperature and salinity data (WOA98) we obtained the same results.

In conclusion, lateral diffusion is the main distributor for water subducted at the southern rim of the gyre, which gradually transforms western into eastern properties. A similar result, with respect to lateral diffusion, was obtained for the deeper thermocline layers of the poleward rim of the North Atlantic subtropical gyre using helium/tritium data (Robbins et al. 2000).

\section{The low-sea surface salinity tongue}

We now investigate why the surface salinity in the southeast Pacific includes a fresh surface tongue $\left(S_{\min }\right)$ centered at approximately $45^{\circ} \mathrm{S}$ and how it is maintained against the mean flow. The precipitation-evaporation balance does not have a local maximum at the $S_{\min }$ core density (Fig. 4d), which is what one would expect if a positive freshwater flux were the reason for the fresh surface tongue.

Zonal mixed layer flow versus mixed layer density shows horizontal shear (Fig. 10) with a minimum at around $26.0 \mathrm{~kg} \mathrm{~m}^{-3}$. This values coincides with the density of freshest surface and interior waters (Figs. 1 and 2). A water parcel that is advected from the west in this weak flow takes the most time to reach the east. Freshwater supplied at the surface through positive

TABLE 2. Lateral diffusion coefficients derived from a hyperbolic fit to temperature and salinity on isopycnals between $20^{\circ}$ and $40^{\circ} \mathrm{S}$ and between $100^{\circ}$ and $160^{\circ} \mathrm{W}$

\begin{tabular}{ccccc}
\hline \hline $\begin{array}{c}\text { Isopycnal (depth) } \\
\left(\mathrm{kg} \mathrm{m}^{-3}\right)\end{array}$ & $\begin{array}{c}160^{\circ} \mathrm{W} \\
T\left({ }^{\circ} \mathrm{C}\right) / S\end{array}$ & $\begin{array}{c}100^{\circ} \mathrm{W} \\
\left({ }^{\circ} \mathrm{C}\right) / S\end{array}$ & $\begin{array}{c}K_{y}\left(10^{3} \mathrm{~m}^{2} \mathrm{~s}^{-1}\right) \\
u=1 \mathrm{~cm} \mathrm{~s}^{-1}\end{array}$ & $\begin{array}{c}K_{y}\left(10^{3} \mathrm{~m}^{2} \mathrm{~s}^{-1}\right) \\
u \text { vertical shear }\end{array}$ \\
\hline $25.5(200 \mathrm{~m})$ & $18.9 / 35.60$ & $18.1 / 35.30$ & $1.5 / 1.2$ & $2.8 / 2.1$ \\
$26.1(280 \mathrm{~m})$ & $16.0 / 35.42$ & $13.2 / 34.65$ & $2.5 / 2.5$ & $2.5 / 2.5$ \\
$26.3(315 \mathrm{~m})$ & $14.7 / 35.25$ & $11.9 / 34.54$ & $2.4 / 2.4$ & $1.9 / 1.9$ \\
$26.5(340 \mathrm{~m})$ & $13.1 / 35.10$ & $10.5 / 34.45$ & $2.4 / 2.5$ & $1.5 / 1.5$ \\
$26.7(390 \mathrm{~m})$ & $11.3 / 34.87$ & $9.2 / 34.40$ & $2.4 / 2.7$ & $1.2 / 1.2$ \\
$26.9(450 \mathrm{~m})$ & $9.1 / 34.63$ & $7.8 / 34.37$ & $3.9 / 3.9$ & $1.4 / 1.4$ \\
$27.0(480 \mathrm{~m})$ & $8.0 / 34.53$ & $7.0 / 34.36$ & $7.9 / 7.2$ & $1.6 / 1.4$ \\
\hline
\end{tabular}




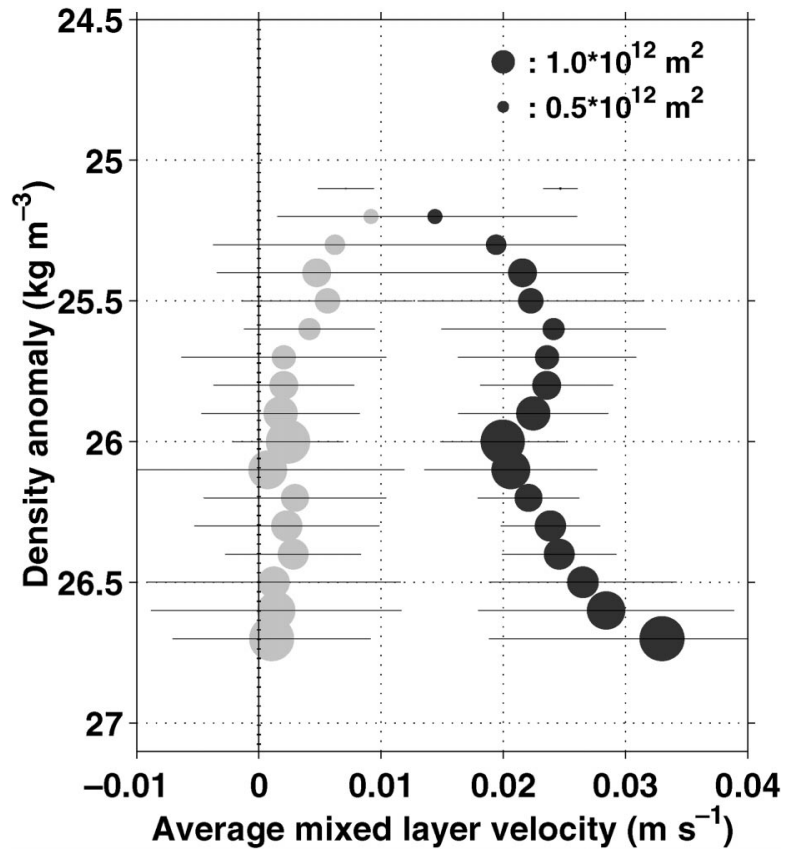

FIG. 10. Average mixed layer flow from SODA analysis fields: zonal (black circles) and meridional (gray circles) component averaged in $0.1 \mathrm{~kg} \mathrm{~m}^{-3}$ density anomaly bins. Horizontal lines are the standard deviation in each density bin. The dot diameters are proportional to the area associated with each density bin.

freshwater flux or advection from the south can modify the "slow" water more than water that is more rapidly advected. The consequence is a tongue of low sea surface salinities centered at the density of the slowest flow. This explanation for the $S_{\min }$ formation does not require westward flow, as expected in the past (Deacon 1977) but never observed (e.g., Tsuchiya and Talley 1998). The mixed layer water is subducted into the thermocline and modifies its properties mainly through lateral diffusion.

\section{Discussion and conclusions}

Watermass transformation in the South Pacific, south of $30^{\circ} \mathrm{S}$, was investigated to explain the formation of the Shallow Salinity Minimum Water and its outcrop, a tongue of low sea surface salinity $\left(S_{\min }\right)$. The $S_{\min }$ l SSMW were found to be the surface/interior manifestation of a large-scale west-to-east watermass transformation of mixed layer and thermocline waters. Freshening is caused by a positive precipitation - evaporation balance and transport processes. Transport here means the import of low salinity and cold water from the south of the subtropical gyre within the northward meridional Ekman transport region. Also, heat is exported by eddies to the south and eddy freshwater fluxes are probably northward. The freshening and cooling affects densities greater than $25.0 \mathrm{~kg} \mathrm{~m}^{-3}$, that is, water having its outcrop south of where the meridional Ekman transport is zero (approximately south of $30^{\circ} \mathrm{S}$ ). The freshest densities in $S_{\min }$ and SSMW are near $26.0 \mathrm{~kg} \mathrm{~m}^{-3}$.

A heat and freshwater budget for the mixed layer was calculated for densities associated with the northward meridional Ekman transport. In the mean, a freshwater volume (flux) of $23 \times 10^{12} \mathrm{~m}^{3}(0.73 \mathrm{~Sv})$ and a heat loss of $-0.43 \mathrm{PW}$ are required to maintain the watermass transformation taking place in the mixed layer. At the eastern boundary of the South Pacific, transformed waters move toward the equator as part of the subtropical gyre circulation. The associated heat flux estimated from the mixed layer budget is similar to the heat flux associated with the shallow overturning circulation of the South Pacific (Talley 2003). The mixed layer budget showed that air-sea exchange and transport from the south both contribute the same volume of freshwater and heat loss. Such pronounced influence of water from south of the subtropical gyre on the composition of SP thermocline water properties is remarkable and in line with the distribution of $\Delta^{14} \mathrm{C}$ (Toggweiler et al. 1991).

The $S_{\min }$ tongue appears to emanate from the eastern boundary centered at about $45^{\circ} \mathrm{S}$. However, in the past no direct evidence for a westward flow was found (Deacon 1977). Because the precipitation - evaporation balance does not have a maximum for lowest salinities in $S_{\text {min }}$, a dynamical explanation but for an eastward flow is suggested. The eastward flow along the southern rim of the subtropical gyre has a minimum where $S_{\text {min }}$ has lowest salinities $\left(\sim 26.0 \mathrm{~kg} \mathrm{~m}^{-3}\right)$. Water of that density experiences the largest freshening during its west-toeast transit and the $S_{\min }$ tongue appears to emanate from the east, against the flow. Sources of the freshening are the positive freshwater flux and the northward advection of low-salinity water from south of the gyre. Sea surface temperature will not form a tongue. This emphasizes a fundamental difference of how atmosphere and ocean communicate in terms of heat and freshwater: heat fluxes and sea surface temperature always feed back on each other while this is not true for freshwater fluxes, making freshwater anomalies a more persistent feature.

The mixed layer water enters the interior at three subduction sites (Fig. 11): in the Tasman Sea to the west (S1), in the east, off Chile (S2), and along the southern rim of the subtropical gyre (S3). The mixed layer and interior pathway is from S1 to S2 in an eastward flow that turns northwestward toward the equator in the east. During advection, mixed layer properties are modified through air-sea interaction and northward transport of fresher and colder water from south of the gyre. The subduction of continuously freshened mixed layer water at the southern rim of the gyre (S3) modifies the interior properties consistent with a diffusion coefficient of order $2000 \mathrm{~m}^{2} \mathrm{~s}^{-1}$ and in agreement with other studies, for example, in the North Atlantic (Robbins et al. 2000). Because that water that subducts in S3 is in part from south of the subtropical gyre it is part of the link between shallow and deep water cells of the "global conveyor 


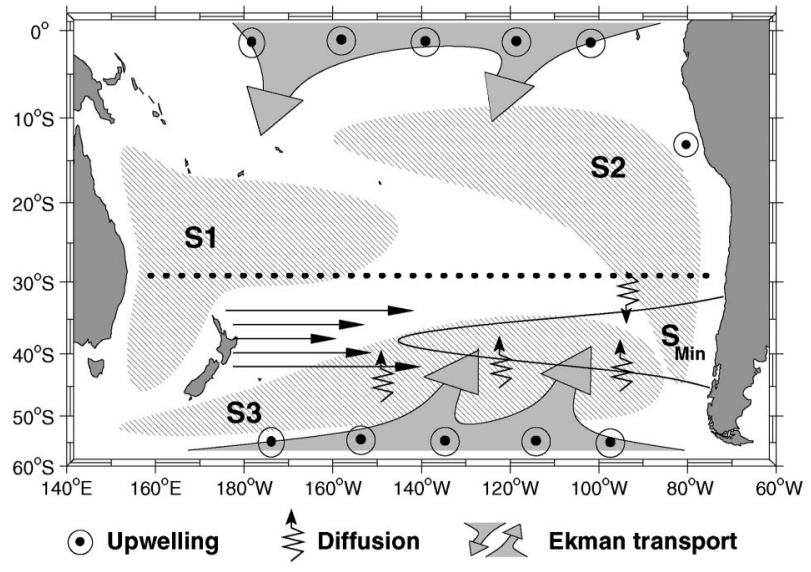

FIG. 11. Schematic representation of the South Pacific STC. Three subduction regions (S1-S3) are fed from the upwelling regions and communicate through mixed layer and interior pathways. The zero meridional Ekman transport line (dotted) separates high- and lowlatitude influence. Subduction along the southern rim of the gyre (S3) modifies the water from S1 via lateral mixing. The shear in the eastward mixed layer flow (arrows) generates a tongue of low sea surface salinities $\left(S_{\min }\right)$. See text for further details.

belt" scheme (e.g., Schmitz 1996; Speer et al. 2000; Rintoul and England 2002).

Subduction in the southeast (S2) is the "classical" downward branch of the South Pacific STC (Gu and Philander 1997; Johnson and McPhaden 1999; McPhaden and Zhang 2002). Here, the densest but freshest part of the STC water is the Shallow Salinity Minimum Water (Reid 1973). Assuming its maximum salinity to be 34.4 , its formation rate is of order $3 \mathrm{~Sv}$ (Fig. 12). Transports increase for more salty waters associated with the South Pacific Eastern Subtropical Mode Water (Hanawa and Talley 2001) to an about $20 \mathrm{~Sv}$ overall formation. Recently, the formation of SPESTMW was found to be of order $9 \mathrm{~Sv}$, but only for those waters with a very low potential vorticity signature $(Q<3 \times$ $10^{-10} \mathrm{~m}^{-1} \mathrm{~s}^{-1}$ ) (Wong and Johnson 2003). The "diffusive" renewal of water denser than that subducted along the South American Coast $\left(>26.1 \mathrm{~kg} \mathrm{~m}^{-3}\right)$ makes the SP lower thermocline ventilation rather sluggish. In combination with the subsurface poleward advection of low-oxygen water along the eastern boundary an extensive oxygen-minimum zone is maintained.

As the freshening of the mixed layer, and subsequently the thermocline, occurs during a number of years, it acts as a "low-pass filter" for variability. This variability could, for example, be introduced from a decadal variability in the wind field changing Ekman transport and Ekman pumping (curl) at the southern rim of the gyre. Indeed, there is support for such a southern SP source of Pacific decadal variability. Garreaud and Battisti (1999) found strongest correlation between decadal variability of an equatorial sea surface temperature index with surface winds and sea level pressure just over the region identified here as the transformation path

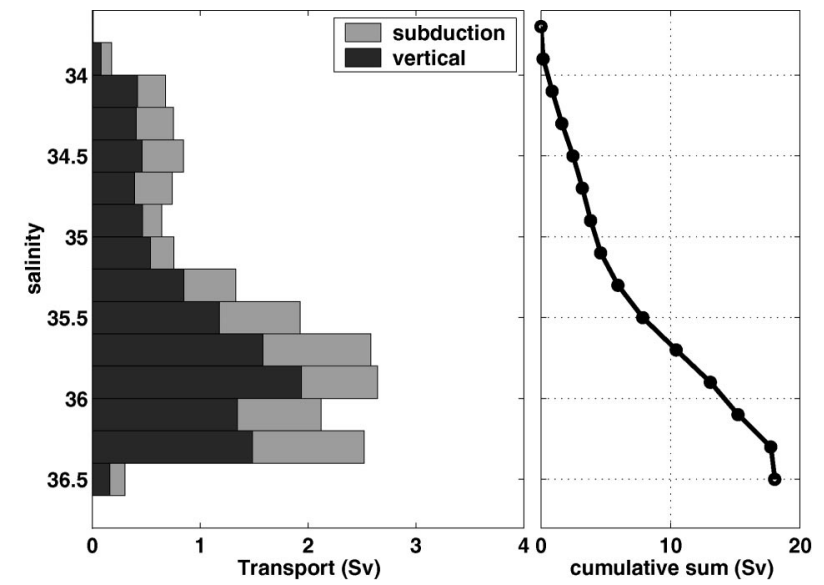

FIG. 12. (left) Transport through subduction in the eastern subduction region in relation to winter mixed layer base salinity. (right) Cumulative transport in the eastern subduction region. For the integration, 0.2-salinity bins have been used.

of mixed layer and thermocline waters. In terms of the extratropical/tropical atmospheric link suggested by $\mathrm{Gu}$ and Philander (1997) it should be noted that precipitation over large parts of the SP is controlled by the location and strength of the South Pacific convergence zone. Hence most of the precipitation that contributes to the formation of $S_{\min }$ should have its origin in the equatorial Pacific.

One further aspect of the SP mixed layer watermass transformation presented here is in relation to the "slow teleconnection" between the El Niño-Southern Oscillation and the Antarctic circumpolar wave. Peterson and White (1998) analyzed Southern Hemisphere sea surface temperature, precipitable water, and sea level pressure data between the mid-1980s and the mid-1990s for propagating anomalies. They report on a southward propagation of anomalies originating from the western subtropical SP (here, western subduction region S1) that are carried into the other oceans with the Antarctic Circumpolar Current on a time scale of 6-8 years. However, in light of the watermass transformation presented here, a shift from stronger to weaker westerly wind stress would reduce the heat and freshwater transport from the south, which in turn would result in an increase of sea surface temperature along the southern rim of the gyre. Such a reduced cooling of the western water could appear as a southward propagation of a sea surface temperature anomaly although it is associated with a northward (but slower) advection. Thus the propagation may be from the Southern Ocean into the Pacific rather then vice versa.

Acknowledgments. This work was supported by the Chilean National Commission for Scientific and Technological Research (CONICYT) through the FONDAP Program. A postdoctoral fellowship from Fundación Andes (Chile) is acknowledged. The NCEP-NCAR reanalysis data were provided by the NOAA-CIRES Cli- 
mate Diagnostics Center, Boulder, Colorado, from their Web site. Many thanks are given to J. Carton, G. Chepurin, and $\mathrm{X}$. Cao for providing the SODA analysis fields. Comments from D. Quadfasel, F. Schott, two reviewers, and L. Talley are acknowledged.

\section{REFERENCES}

Carton, J. A., G. Chepurin, and X. Cao, 2000a: A simple ocean data assimilation analysis of the global upper ocean 1950-1995. Part II: Results. J. Phys. Oceanogr., 30, 311-326.

$-, \ldots, \ldots$, and B. S. Giese, 2000b: A simple ocean data assimilation analysis of the global upper ocean 1950-1995. Part I: Method. J. Phys. Oceanogr., 30, 294-309.

Cushman-Roisin, B., 1987: Subduction. Dynamics of the Oceanic Surface Mixed Layer: Proc. 'Aha Huliko'a Hawaiian Winter Workshop, Honolulu, HI, University of Hawaii at Manoa, 181196.

da Silva, A. M., C. C. Young, and S. Levitus, 1994a: Anomalies of Fresh Water Fluxes. Vol. 4, Atlas of Surface Marine Data 1994, NOAA Atlas NESDIS 9, 308 pp.

$\ldots$, - and _- 1994b: Anomalies of Heat and Momentum Fluxes. Vol. 3, Atlas of Surface Marine Data 1994, NOAA Atlas NESDIS 8, $411 \mathrm{pp}$.

Davila, P. M., D. Figueroa, and E. Müller, 2002: Freshwater input into the coastal ocean and its relation with the salinity distribution off austral Chile $\left(35-55^{\circ} \mathrm{S}\right)$. Cont. Shelf Res., 22, 521534.

Deacon, G. E. R., 1977: Comments on a counterclockwise circulation in the Pacific subantarctic sector of the Southern Ocean suggested by McGinnis. Deep-Sea Res., 24, 927-930.

de Szoeke, R. D., 1987: On the wind-driven circulation of the South Pacific Ocean. J. Phys. Oceanogr., 17, 613-630.

Emery, W. J., and J. Meincke, 1986: Global water masses: Summary and review. Oceanol. Acta, 9, 383-391.

Garreaud, R. D., and D. S. Battisti, 1999: Interannual (ENSO) and interdecadal (ENSO-like) variability in the Southern Hemisphere tropospheric circulation. J. Climate, 12, 2113-2123.

Gent, P. R., J. Willebrand, T. J. McDougall, and J. C. McWilliams, 1995: Parameterizing eddy-induced tracer transports in ocean circulation models. J. Phys. Oceanogr., 25, 463-474.

Gill, A. E., 1982: Atmosphere-Ocean Dynamics. Academic Press, $662 \mathrm{pp}$

Gordon, A. L., S. Ma, D. B. Olson, P. Hacker, A. Ffield, L. D. Talley, D. Wilson, and M. Baringer, 1997: Advection and diffusion of Indonesian Throughflow Water within the Indian Ocean South Equatorial Current. Geophys. Res. Lett., 24, 2573-2576.

Grist, J. P., and S. A. Josey, 2003: Inverse analysis adjustment of the SOC air-sea flux climatology using ocean heat transport constraints. J. Climate, 16, 3274-3295.

Gu, D., and G. Philander, 1997: Interdecadal climate fluctuations that depend on exchange between the Tropics and the extratropics. Science, 275, 805-807.

Hanawa, K., and L. D. Talley, 2001: Mode waters. Ocean Circulation and Climate, G. Siedler, J. Church, and J. Gould, Eds., Academic Press, 373-386.

Huang, R. X., and B. Qiu, 1998: The structure of the wind-driven circulation in the subtropical South Pacific Ocean. J. Phys. Oceanogr., 28, 1173-1186.

Johnson, G. C., 2001: The Pacific Ocean subtropical cell surface limb. Geophys. Res. Lett., 28, 1771-1774.

—_, and M. McPhaden, 1999: Interior pycnocline flow from the subtropical to the equatorial Pacific Ocean. J. Phys. Oceanogr. 29, 3073-3089.

Josey, S. A., E. C. Kent, and P. K. Taylor, 1998: The Southampton Oceanography Centre (SOC) Ocean-Atmosphere Heat, Momentum and Freshwater Flux Atlas. Southampton Oceanography Centre Tech. Rep. 6, 30 pp.

$\ldots, \ldots$, and -2002 : Wind stress forcing of the ocean in the
SOC climatology: Comparisons with the NCEP-NCAR, ECMWF, UWM/COADS, and Hellerman and Rosenstein datasets. J. Phys. Oceanogr., 32, 1993-2019.

Karstensen, J., and D. Quadfasel, 2002: Formation of Southern Hemisphere thermocline waters: Water mass conversion and subduction. J. Phys. Oceanogr., 32, 3020-3038.

Kistler, R., and Coauthors, 2001: The NCEP-NCAR 50-Year Reanalysis: Monthly means CD-ROM and documentation. Bull. Amer. Meteor. Soc., 82, 247-267.

Kleeman, R., J. P. McCreary Jr., and B. A. Klinger, 1999: A mechanism for generating ENSO decadal variability. Geophys. Res. Lett., 26, 1743-1746.

Levitus, S., T. Boyer, M. Conkright, D. Johnson, T. O’Brien, J. Antonov, C. Stephens, and R. Gelfeld, 1998: Introduction. Vol. 1, World Ocean Database 1998, NOAA Atlas NESDIS 18, 346 pp.

Luyten, J., J. Pedlosky, and H. Stommel, 1983: The ventilated thermocline. J. Phys. Oceanogr., 13, 292-309.

Marshall, J. C., A. J. G. Nurser, and R. G. Williams, 1993: Inferring the subduction rate and period over the North Atlantic. J. Phys. Oceanogr., 23, 1315-1329.

—_ D. Jamous, and J. Nilsson, 1999: Reconciling thermodynamic and dynamic methods of computation of water-mass transformation. Deep-Sea Res., 46, 545-572.

-, H. Jones, R. Karsten, and R. Wardle, 2002: Can eddies set ocean stratification? J. Phys. Oceanogr., 32, 26-38.

McCartney, M. S., 1977: Subantarctic Mode Water. A Voyage of Discovery, Vol. 24 (Suppl.), M. Angel, Ed., Pergamon Press, 103-119.

McCreary, J. P., and P. Lu, 1994: Interaction between subtropical and equatorial ocean circulations: The subtropical cell. J. Phys. Oceanogr., 24, 466-497.

McPhaden, M. J., and D. Zhang, 2002: Slowdown of the meridional overturning circulation in the upper Pacific Ocean. Nature, 415, 603-608.

Meinen, C. S., M. J. McPhaden, and G. C. Johnson, 2001: Vertical velocities and transports in the equatorial Pacific during 19931999. J. Phys. Oceanogr., 31, 3230-3248.

Molinelli, E., 1978: Isohaline thermoclines in the southeast Pacific Ocean. J. Phys. Oceanogr., 8, 1139-1145.

Neshyba, S., and T. R. Fonseca, 1980: Evidence for counterflow to the west wind drift off South America. J. Geophys. Res., 85, $4888-4892$.

Peterson, R. G., and W. B. White, 1998: Slow oceanic teleconnections linking the Antarctic Circumpolar Current wave with the tropical El Niño-Southern Oscillation. J. Geophys. Res., 103, $24573-$ 24583.

Qiu, B., and R. X. Huang, 1995: Ventilation of the North Atlantic and North Pacific: Subduction versus obduction. J. Phys. Oceanogr., 25, 2374-2390.

Reid, J. L., 1973: The shallow salinity minima of the Pacific Ocean. Deep-Sea Res., 20, 51-68.

Rintoul, S. R., and M. H. England, 2002: Ekman transport dominates local air-sea fluxes in driving variability of Subantarctic Mode Water. J. Phys. Oceanogr., 32, 1308-1321.

Robbins, P., J. Price, W. Owens, and W. Jenkins, 2000: On the importance of lateral diffusion for the ventilation of the lower thermocline in the subtropical North Atlantic. J. Phys. Oceanogr., 30, 67-89.

Rodgers, K. B., B. Blanke, G. Madec, O. Aumont, P. Ciais, and J.-C. Dutay, 2003: Extratropical sources of equatorial Pacific upwelling in an OGCM. Geophys. Res. Lett., 30, 1089, doi: 10.1029/2002GL016003.

Roemmich, D., and B. Cornuelle, 1992: The subtropical mode waters of the South Pacific Ocean. J. Phys. Oceanogr., 22, 1178-1187. , and J. Gilson, 2001: Eddy transport of heat and thermocline waters in the North Pacific: A key to interannual/decadal climate variability? J. Phys. Oceanogr., 31, 675-687.

Rothstein, L. M., R.-H. Zhang, A. J. Busalacchi, and D. Chen, 1998: A numerical simulation of the mean water pathways in the sub- 
tropical and tropical Pacific Ocean. J. Phys. Oceanogr., 28, 322343.

Rowe, G. D., E. Firing, and G. C. Johnson, 2000: Pacific equatorial subsurface countercurrent velocity, transport, and potential vorticity. J. Phys. Oceanogr., 30, 1172-1187.

Schmitz, W. R., Jr., 1996: On the World Ocean Circulation: Volume II. Woods Hole Oceanographic Institution Tech. Rep. WHOI96-08, 237 pp.

Schneider, N., S. Venzke, A. J. Miller, D. W. Pierce, T. P. Barnett, C. Deser, and M. Latif, 1999: Pacific thermocline bridge revisited. Geophys. Res. Lett., 26, 1329-1332.

Schneider, W., R. Fuenzalida, E. Rodríguez-Rubio, J. Garcés-Vargas, and L. Bravo, 2003: Characteristics and formation of Eastern South Pacific Intermediate Water. Geophys. Res. Lett., 30, 1581, doi:10.1029/2003GL017086.

Schott, F., M. Dengler, and R. Schoenefeldt, 2002: The shallow overturning circulation of the Indian Ocean. Progress in Oceanography, Vol. 53, Pergamon, 57-103.

— J. P. McCreary Jr., and G. C. Johnson, 2004: Shallow overturning circulations of the tropical-subtropical oceans. Earth Climate: The Ocean-Atmosphere Interaction, Geophys. Monogr. Vol. 147, Amer. Geophys. Union, in press.

Smith, S. R., D. M. Legler, and K. V. Verzone, 2001: Quantifying uncertainties in NCEP reanalysis using high-quality research vessel observations. J. Climate, 14, 4062-4072.

Speer, K., S. R. Rintoul, and B. Sloyan, 2000: The diabatic Deacon cell. J. Phys. Oceanogr., 30, 3212-3222.

Stommel, H., 1979: Determination of water mass properties of water pumped down from the Ekman layer to the geostrophic flow below. Proc. Natl. Acad. Sci. USA, 76, 3051-3055.

Stramma, L., R. G. Peterson, and M. Tomczak, 1995: The South Pacific Current. J. Phys. Oceanogr., 25, 77-91.

Talley, L. D., 2003: Shallow, intermediate, and deep overturning com- ponents of the global heat budget. J. Phys. Oceanogr., 33, 530560.

Toggweiler, J. R., K. Dixon, and W. S. Broecker, 1991: The Peru upwelling and the ventilation of the South Pacific thermocline. J. Geophys. Res., 96, 20 467-20 497.

Tsuchiya, M., and L. Talley, 1996: Water-property distribution along an eastern Pacific hydrographic section at 135W. J. Mar. Res., 54, 541-564.

— and — 1998: A Pacific hydrogaphic section at $88^{\circ} \mathrm{W}$ : Waterproperty distribution. J. Geophys. Res., 103, 12 899-12 918.

Wijffels, S., E. Firing, and H. Bryden, 1994: Direct observations of the Ekman balance at $10^{\circ} \mathrm{N}$ in the Pacific. J. Phys. Oceanogr., 24, 1666-1679.

Williams, R. G., 1989: The influence of air-sea interaction on the ventilated thermocline. J. Phys. Oceanogr., 19, 1255-1267.

WOCE Data Products Committee, 2000: WOCE Global Data, version 2.0. WOCE Hydrographic Programme Rep. 171/00, WOCE International Project Office, Southampton, United Kingdom.

Wong, A. P. S., and G. C. Johnson, 2003: South Pacific Eastern Subtropical Mode Water. J. Phys. Oceanogr., 33, 1493-1509.

Woods, J. D., 1985: Physics of thermocline ventilation. Coupled Ocean-Atmosphere Models, J. C. J. Nihoul, Ed., Elsevier, 543590.

Wyrtki, K., 1981: An estimate of equatorial upwelling in the Pacific. J. Phys. Oceanogr., 11, 1205-1214.

Yeager, S. G., and W. G. Large, 2004: Late-winter generation of spiciness on subducted isopycnals. J. Phys. Oceanogr., 34, $1528-1547$.

Zhang, D., M. J. McPhaden, and W. Johns, 2003: Observational evidence for flow between the subtropical and tropical Atlantic: The Atlantic subtropical cells. J. Phys. Oceanogr., 33, 17831797.

Zhang, Y. Z., J. M. Wallace, and D. S. Battisti, 1997: ENSO-like interdecadal variability: 1900-1993. J. Climate, 10, 1004-1020. 